\title{
Sell in May and Go Away Exposed!
}

\author{
Dr. Ladd Kochman ${ }^{1 *} \&$ Dr. David Bray ${ }^{1}$ \\ ${ }^{1}$ Economics, Finance and Quantitative Analysis, Coles College of Business, Kennesaw State \\ University, Kennesaw, USA \\ ${ }^{*}$ Dr. Ladd Kochman, E-mail: 1kochman@kennesaw.edu
}

Received: August 30, 2017 Accepted: September 16, 2017 Online Published: September 30, 2017

doi:10.22158/rem.v2n5p172 URL: http://dx.doi.org/10.22158/rem.v2n5p172

\begin{abstract}
Despite continuing success for the sell-in-May effect, returns from the January-February segment of the six-month period proved surprisingly flat. Between 1995 and 2015, March-April and November-December had mean returns of 5.11 percent and 3.33 percent, respectively, while January-February averaged -0.04 percent. Nonetheless, the annualized return for November-April was nearly six times greater than that for May-October.
\end{abstract}

\section{Keywords}

sell-in-May, trading

\section{Background}

The trading strategy of buying stocks in November and divesting them in May is popularly known as the Sell in May and Go Away effect. Returns from the November-April period have generally been found to beat those from May-October by double-digit margins. Bauman and Jacobsen (2002) found a difference of 11.1 percent (17.1 percent versus 6.0 percent) when returns for the two six-month periods were annualized over the 1970-1998 span. Kochman and Badarinathi (2008) reported annualized returns of 15.57 percent (November-April) and 9.07 percent (May-October) for 1926-2004 and a greater margin of 13.6 percent for 1970-2004. Andrade et al. (2013) identified an advantage of 10 percent between 1998 and 2012. When Kochman et al. (2014) annualized returns from November-April and May-October between 2004 and 2012, the former period again dominated-10.08 percent versus 1.18 percent.

Some studies have concluded that no such anomaly exists. They include Maberly and Pierce (2004), Fuller et al. (2013) and Dichtl and Drobetz (2014). Others such as Jones and Lundstrum (2009) and Dichtl and Drobetz (2015) have conceded that superior returns from November to April were possible but only in certain years. A final group of detractors attributed anomalous returns from November-April to other seasonal effects. Lucey and Zhao (2006) and Haggard and Witte (2010) cited 
the January effect while Beladi et al. (2016) pointed to special dividends in December-the Christmas effect.

\section{Methodology}

Not unlike Kochman et al., we collected returns for the Standard \& Poor 500 index from the www.bigcharts.com website to test the sell-in-May effect. However, unlike previous studies, we were interested in learning how each two-month segment in the November-April span contributed to the alleged anomaly. Hence, changes in the index from November 1 to December 31, from January 1 to February 28 or 29 and from March 1 to April 30 were identified and converted to 60 two-month returns-or 20 per segment-between November 1995 and April 2015. Six-month returns for the May-October period were likewise derived from changes in the S\&P 500 index per www.bigcharts.com.

\section{Results}

Those two-month changes in the S\&P 500 index between November and April beginning in 1995 and ending in 2015 revealed that only the March-April (5.11 percent) and November-December (3.33 percent) segments of the six-month period were responsible for a compounded return of 8.18 percent (Note 1) (or 17.02 percent) when annualized. The January-February segment actually lost four basis points per year. See Table 1.

Table 1. Two-Month S\&P 500 Returns (1996-2015)

\begin{tabular}{lllll}
\hline Year & Nov-Dec & Jan-Feb & Mar-Apr & Combined \\
\hline 2015 & $2.02 \%$ & $2.21 \%$ & $-0.90 \%$ & $3.34 \%$ \\
2014 & $5.23 \%$ & $0.60 \%$ & $1.32 \%$ & $7.26 \%$ \\
2013 & $0.99 \%$ & $6.20 \%$ & $5.47 \%$ & $13.12 \%$ \\
2012 & $0.34 \%$ & $9.11 \%$ & $1.88 \%$ & $11.54 \%$ \\
2011 & $6.31 \%$ & $5.51 \%$ & $2.74 \%$ & $15.24 \%$ \\
2010 & $7.62 \%$ & $-0.95 \%$ & $9.26 \%$ & $16.47 \%$ \\
2009 & $-6.76 \%$ & $-18.62 \%$ & $18.72 \%$ & $-9.92 \%$ \\
2008 & $-5.23 \%$ & $-6.86 \%$ & $1.31 \%$ & $-10.57 \%$ \\
2007 & $2.93 \%$ & $-0.81 \%$ & $5.37 \%$ & $7.58 \%$ \\
2006 & $3.42 \%$ & $2.59 \%$ & $15.75 \%$ & $22.81 \%$ \\
2005 & $7.23 \%$ & $-0.69 \%$ & $8.89 \%$ & $15.96 \%$ \\
2004 & $5.83 \%$ & $2.97 \%$ & $1.04 \%$ & $10.11 \%$ \\
2003 & $-0.67 \%$ & $-4.40 \%$ & $9.01 \%$ & $3.52 \%$ \\
2002 & $8.33 \%$ & $-3.60 \%$ & $-2.69 \%$ & $1.62 \%$ \\
\hline
\end{tabular}




\begin{tabular}{llllll}
\hline 2001 & $-7.63 \%$ & $-6.09 \%$ & $0.77 \%$ & $-12.59 \%$ & \\
2000 & $7.80 \%$ & $-8.25 \%$ & $7.74 \%$ & $6.56 \%$ & \\
1999 & $11.88 \%$ & $0.74 \%$ & $7.82 \%$ & $21.52 \%$ & \\
1998 & $6.10 \%$ & $8.13 \%$ & $5.95 \%$ & $20.55 \%$ & \\
1997 & $5.03 \%$ & $6.76 \%$ & $1.33 \%$ & $13.62 \%$ & \\
1996 & $5.92 \%$ & $4.68 \%$ & $1.46 \%$ & $12.50 \%$ & \\
Mean & $\mathbf{3 . 3 3 \%}$ & $\mathbf{- 0 . 0 4 \%}$ & $\mathbf{5 . 1 1 \%}$ & $\mathbf{8 . 5 6 \%}$ & $\mathbf{1 0 . 3 5 \%}$ \\
S.D. & & & & & \\
\hline
\end{tabular}

Alternatively, the 20 six-month periods between May and October for years 1996-2015 produced a combined effect of 1.44 percent (Note 1) (or 2.91 percent annually) when the May-June, July-August and September-October segments experienced changes of 0.39 percent, -0.60 percent and 1.66 percent, respectively. See Table 2 .

Table 2. Combined Effect of Two-Month Returns from May-October (1996-2015)

\begin{tabular}{llll}
\hline Year & Effect & Year & Effect \\
\hline 2015 & $-0.29 \%$ & 2004 & $14.60 \%$ \\
2014 & $7.12 \%$ & 2003 & $-17.75 \%$ \\
2013 & $9.96 \%$ & 2002 & $-15.18 \%$ \\
2012 & $1.02 \%$ & 2001 & $-1.59 \%$ \\
2011 & $-8.09 \%$ & 2000 & $2.08 \%$ \\
2010 & $-0.28 \%$ & 1999 & $-1.17 \%$ \\
2009 & $18.73 \%$ & 1998 & $14.14 \%$ \\
2008 & $-30.08 \%$ & 1997 & $7.81 \%$ \\
2007 & $4.52 \%$ & 1996 & $12.97 \%$ \\
2006 & $4.33 \%$ & Mean & $\mathbf{1 . 2 5 \%}$ \\
2005 & $2.07 \%$ & S.D. & $\mathbf{1 1 . 8 8 \%}$ \\
\hline
\end{tabular}

The failure of January and February to contribute to our pronounced sell-in-May effect appears to be more time-specific than intractable. The January-February average return for 2010-2014 was 4.73 percent - or 31.95 percent annualized. By contrast, the November-December and March-April segments averaged only 2.98 percent (or 19.25 percent annualized) and 2.10 percent (or 13.39 percent annualized), respectively, for the same five-year period. Trending returns from January-February and transaction costs should give pause to any strategy that buys stocks in November, liquidates them in January and repurchases them in March. 


\section{Conclusions}

The contribution of this study to the literature seems twofold. One, we provided recent evidence of the existence of the sell-in-May anomaly. The annualized average return from the S\&P 500 stocks for the November-April period was nearly six times greater than its May-October counterpart over the 20 years ending in October 2015. Two, we exposed an historical weak link in the six-month chain (January-February) that thwarted an even more impressive sell-in-May effect. If the January effect were ever responsible for the sell-in-May anomaly, it certainly was not true in the last 20 years.

Some researchers have argued that the sell-in-May effect is time-specific at best-generating anomalous returns in some years but not in others. Others have acknowledged the effect but claimed it had weakened over time. For them, no explanation of the phenomenon was deemed necessary. But for the majority of academic writers who hailed the effect as a bona fide exception to the efficient market hypothesis, attempts were made to explain it. The usual reasons were vacationing investors and slower efforts to arbitrage away inefficiencies. The best one may have been provided by Kochman et al. who designated the anomaly as simply a self-fulfilling prophecy.

\section{Update}

Adding returns from November-December 2015, January-February 2016 and March-April 2016 resulted in a combined sell-in-May effect of -0.67 percent. The November-December and January-February segments suffered losses of 1.70 percent and 4.69 percent, respectively, while March-April generated a gain of 6.02 percent. Conversely, the three two-month segments between May and October 2016 saw changes of 1.62 percent, 3.43 percent and -2.06 percent for a combined effect of 2.94 percent. The superior combined return for May-October 2016 is only the fifth time since 1996 that the November-April segment failed to beat its May-October counterpart. The other years were 1996, 2001, 2004 and 2009.

\section{References}

Andrade, S., Chhaochharia, V., \& Fuerst, M. (2013). Sell in May and Go Away Won't Go Away. Financial Analysts Journal, 2013. https://doi.org/10.2469/faj.v69.n4.4

Bauman, S., \& Jacobsen, B. (2002). The Halloween Indicator, Sell in May and Go Away: Another Puzzle. American Economic Review, 2002. https://doi.org/10.1257/000282802762024683

Beladi, H., Chao, C., \& Hu, M. (2016). The Christmas Effect: Special Dividend Announcements. International Review of Financial Analysts, 2016. https://doi.org/10.1016/j.irfa.2015.10.004

Dichtl, H., \& Drobetz, W. (2014). Are Stock Markets Really So Efficient? The Case of the Halloween Indicator. Financial Research Letters, 2014. https://doi.org/10.1016/j.frl.2013.10.001

Dichtl, H., \& Drobetz, W. (2015). Sell in May and Go Away: Still Good Advice for Investors. International Review of Financial Analysts, 2015. https://doi.org/10.1016/j.irfa.2014.09.007 
Fuller, P., Yu, G., \& Boudreaux, D. (2012). Should Investors Be Fearful of the Halloween Effect? South western Economic Review, 2012.

Haggard, K., \& Witte, H. (2010). The Halloween Effect: Trick or Treat. International Review of Financial Analysts, 2010. https://doi.org/10.1016/j.irfa.2010.10.001

Jones, C., \& Lundstrum, L. (2009). Is Sell in May and Go Away a Valid Strategy for U.S. Equity Allocation? Journal of Wealth Management, 2009. https://doi.org/10.3905/JWM.2009.12.3.104

Kochman, L., \& Badarinathi, R. (2008). The Halloween Effect: An Enduring Market Anomaly. Finance India, 2008.

Kochman, L., Badarinathi, R., \& Bray, D. (2014). Sell in May and Go Away Revisited. American Economist, 2014. https://doi.org/10.1177/056943451405900108

Lucey, B., \& Zhao, S. (2006). Halloween or January? Yet Another Puzzle. International Review of Financial Analysts, 2006. https://doi.org/10.2139/ssrn.887861

Maberly, E., \& Pierce, R. (2004). Stock Market Efficiency Withstands Another Challenge: Solving the Sell in May/Buy After Halloween Puzzle. Economics Journal Watch, 2004.

\section{Note}

Note 1 . The combined return based on the three two-month means is not necessarily the same as the combined return based on the 20 yearly combined returns. 